EGU21-177

https://doi.org/10.5194/egusphere-egu21-177

EGU General Assembly 2021

(c) Author(s) 2022. This work is distributed under

the Creative Commons Attribution 4.0 License.

\title{
Balance between tectonics and sedimentation during geodynamic evolution of the Adria-Europe convergence zone in central Serbia
}

\author{
Uros Stojadinovic ${ }^{1}$, Nemanja Krstekanić ${ }^{1,2}$, Bojan Kostić ${ }^{1}$, and Tamara Bogdanović ${ }^{3}$ \\ ${ }^{1}$ Faculty of Mining and Geology, University of Belgrade, Belgrade, Serbia. \\ ${ }^{2}$ Faculty of Geosciences, Utrecht University, Utrecht, The Netherlands. \\ ${ }^{3}$ Cotango d.o.o., Rudnik, Serbia.
}

The Cretaceous sedimentation along the NE Dinarides margin was associated with subduction and collision of the Neotethys Ocean located between continental units of Adria and Europe (i.e., the Sava subduction system). In this region, we have performed a coupled kinematic and sedimentological study in order to understand the main controlling mechanism of deposition in basins situated above the Sava subduction zone.

The Cretaceous sedimentation on the upper plate of the Sava subduction system took place in a fore-arc basin developed in frontal parts of the active European continental margin. The sedimentary facies indicate three cycles of deposition during Early Cretaceous-Cenomanian, Turonian-Santonian, and Campanian-Maastrichtian. Lower Cretaceous-Cenomanian deposition was associated with regional contraction and characterized by the clastic-carbonatic cyclic shelf and slope deposits (i.e., the "para-flysch"). The European fore-arc "para-flysch" sequences, deposited during Berriasian-Aptian times, presently outcrop in the Gledićke Mts and Rudnik area in central Serbia. Following the Albian-Cenomanian regression that created regional unconformity across the entire fore-arc domain, Turonian-Santonian extension resulted in subsidence and syndepositional bimodal magmatism. Fore-arc syn-subductional extension was triggered by retreating and steepening of the subducting Neotethys lithosphere. The final Campanian-Maastrichtian regression was initiated by large-scale shortening during the onset of Adria-Europe collision.

Unlike the European fore-arc domain, the Cretaceous sedimentation over the passive continental margin of the Dinarides was exclusively controlled by continuous shortening and overall transgression over the subducting Adria plate. Deposition starts with transgressive Albian-Cenomanian coarse-clastics and gradually deepens into the clastic-carbonatic shelf deposits. Rapid subsidence since the late Turonian resulted in deposition of slope carbonates followed by the deep pelagic sedimentation of Coniacian to Campanian-Maastrichtian limestones with cherts (i.e., the Struganik facies). The onset of deposition in the Sava subduction trench, as well as the accelerated subsidence in the entire lower Adria plate domain was coeval with Turonian-Coniacian switch to syn-subductional extension in the European fore-arc basin. The trench sedimentation starts with Turonian distal mudstones overlain by Coniacian-Maastrichtian clastic-carbonatic turbidites, as observed in the Rudnik Formation in Central Serbia. The westward 
expansion and migration of trench deposition towards the lower Adria plate culminated with Middle Campanian-Late Maastrichtian deposition of siliciclastic trench turbidites observed in the Ljig Formation.

The onset of the latest Cretaceous-Paleogene Adria-Europe continental collision resulted in largescale W-wards thrusting that inverted the Cretaceous basins along NE Dinarides margin and emplaced sedimentary infill and basement of the European fore-arc over the Sava trench turbidites. The continued continental collision led to the propagation of thrusting during Eocene, which was characterized by formation of the large offset out-of-sequence thrusts. The eduction that followed break-off of the Neotethys slab beneath the Dinarides triggered Oligocene-Miocene extension which reactivated the inherited thrust contacts as extensional detachments along the entire Dinarides margin. The extension exhumed the lower Adria plate and additionally fragmented and deformed the former Cretaceous basins. The rates of extensional exhumation are decreasing to the NE, from the Dinarides margin towards the Carpathians. 